Journal of English Language Teaching and Applied Linguistics

ISSN: 2707-756X

DOI: $10.32996 /$ jeltal

Journal Homepage: www.al-kindipublisher.com/index.php/jeltal

JELTAL

\title{
The Impact of Critical Thinking on HUFI English-major Freshmen's Essay Writing
}

\author{
Vo Thi Thu Thao 8 (D) \\ Ho Chi Minh City University of Food Industry, Ho Chi Minh City, Vietnam \\ $\triangle$ Corresponding Author: Vo Thi Thu Thao, E-mail: thaovtt@hufi.edu.vn
}

\section{ARTICLE INFORMATION ABSTRACT}

Received: May 15, 2021

Accepted: June 08, 2021

Volume: 3

Issue: 6

DOI: $10.32996 /$ jeltal.2021.3.6.11

\section{KEYWORDS}

Critical thinking; critical thinking skills; essay writing; essay writing process
According to the final test results of writing courses, it is indicated that the essay writing process has been still a radical challenge among HUFI English-major students. This paper illustrates a preliminary study in which English-major students' perceptions about how critical thinking skills impact their process of writing short essays is investigated. To verify the issue, survey research and classroom observations were planned and conducted. A set of questionnaires was first handed out to 120 students in the Writing 2 course (Essay Writing) to explore students' insights on the importance of critical thinking in their writing, and then six sections of students' in-class writing were observed to identify both benefits and challenges of applying critical thinking skills to the essay writing task. The findings indicated that critical thinking plays a crucial role in enhancing students' ability to plan and capacity to write essays as well as minimizing weaknesses in students' essay writing process.

\section{Introduction}

These days' demands of second language learners have made traditional forms of language instructions inadequate for satisfying learners' desire for proficiency in communication. Therefore, the method of communicative language teaching was developed, in which the building blocks of task-based instruction were offered. Critical thinking was considered one of the indispensable parts of those blocks, one prerequisite skill in higher education (McMillan, 1987). It aims to promote students' success in the modern area and is also linked to problem-solving ability. Critical thinking tasks were well-known as one of the practicable strategies for improving learners' skills, such as writing (Bacha, 2010). The ability to think critically has certainly been an expected component among English language teachers and learners. Yet, applying critical thinking is still a real challenge in English as a foreign language classroom.

Fisher (2011) also shows that, recently, critical thinking has become a trend in the educational setting. Whatever purpose it is for, educators have been very keen on teaching thinking skills of several kinds in comparison with teaching content or information only. Of course, both teaching methods can be employed, but previously the emphasis in teaching has been on teaching content - history, physics, geography, or whatever. Although many educators would admit teaching their students how to think, most would claim that this is carried out indirectly or implicitly in the course of teaching a special subject. Moreover, educators have doubted the effectiveness of teaching critical thinking skills in this way since most students simply do not bring these skills into question. As a result, many teachers have become increasingly focused on teaching these skills directly. It means that a range of transferable thinking skills might be instructed explicitly and directly. Fisher (2011) also defines that the skills in question are critical thinking skills, and they will be directed in a way that aims to enhance their transfer to other fields and other contexts.

Moreover, in the globalized world of information, critical thinking skills, no exception, play a crucial role in Vietnamese tertiary education in general and particularly in second and foreign language teaching and learning. It is increasingly necessary for students to gain more profound knowledge about a specific language course and improve their ability to develop a topic academically. Additionally, English academic writing skills are mandatory for English majors at the Vietnamese university level in which students normally enrol in three basic writing courses, from writing paragraphs to writing short and long essays. The obvious purpose of this is to create graduates who communicate effectively either in oral cases or in written ones, which might

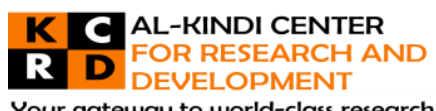

Your gateway to world-class research

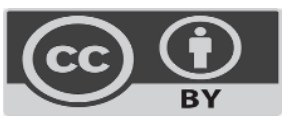

Published by Al-Kindi Center for Research and Development, United Kingdom. Copyright (c) the author(s). This open access article is distributed under a Creative Commons Attribution (CC-BY) 4.0 license 
be regarded as one of the most demanding skills to acquire in EFL contexts. Also, teaching writing has also been one of the most urgent and significant tasks. An amount of research has been conducted on the relationship between various teaching methods and students' writing ability. However, there has been little research on the impact of critical thinking on students' essay writing learning process. As a result, this study illustrates an investigation of English-major students' perceptions about how critical thinking skills influence their writing essays.

\section{Literature Review}

\subsection{Critical thinking}

Critical thinking is defined and discussed by many scholars. According to Cottrell (2005), critical thinking is assumed as a complicated process of deliberation involving a host of skills and attitudes, be it identifying other people's positions, evaluating the evidence, weighing up opposing arguments, being able to read between the lines, recognizing techniques, reflecting on issues, drawing conclusions, and presenting a point of view.

Paul and Elder (2006) define critical thinking as a form of disciplined, self-directed, self-corrective, and self-monitored thinking. Critical thinking is regarded as the cognitive strategy to argue one's opinion, make a decision, and reflect and weigh communicative manners (Nugent and Vitale, 2008). Besides, critical thinking ability is defined as thinking logically and reflectively (Wang, 2009). It is claimed that this ability enables learners to freely present their own ideas, show and describe how the ideas interrelated, and then produce higher thinking levels.

Daniel \& Auriac (2011) state that critical thinking is not inherent but can be acquired and developed through instructional training because it is a cognitive skill. Doyle (2020) mentions that critical thinking defines the ability to objectively analyze information and reach a reasoned judgment.

\subsection{Benefits of critical thinking skills}

Several other scholars have also paid attention to the leaners' ability to deliberate and judge how any given piece of information is truthful enough to accept. Research shows a connection between critical thinking and learning, in general, and foreign language learning, in particular. McCutcheon \& Apperson (1992) suggest that students with critical thinking are more likely to ask questions and not to accept answers easily; instead, the pieces of information might be analyzed logically and used to draw conclusions about the world. Those with this ability might become successful learners. In addition, those who think critically must be consistent in what they say or believe.

Richards and Schmidt (2002) advise that in language teaching, critical thinking is supposed as a level as the learner could raise questions on what is perceived.

Cottrell (2005) lists numerous benefits of good critical thinking skills. Moreover, the researcher also adds that:

"Skills in critical thinking bring precision to the way you think and work. You will find that practice in critical thinking helps you to be more accurate and specific in noting what is relevant and what is not. The skills listed above are useful to problem-solving and to project management, bringing greater precision and accuracy to different parts of a task. Although critical thinking can seem like a slow process because it is precise, once you have acquired good skills, they save you time because you learn to identify the most relevant information more quickly and accurately."

In addition, critical thinking is divided into several sub-skills, such as observation, reasoning, decision-making, analysis, judgment, and persuasion. Also, it involves mastering skills like categorizing, selection and differentiation, comparing and contrasting. To develop the foundation of critical thinking, it is necessary to understand the skills like interpretation, inference, explanation, selfregulation, and evaluation of one's own judgments (Facione, 2009).

Thomas (2011) emphasizes that critical thinking plays an essential part in students' process of development at the tertiary level. Creating well-round learners is an important task these days, leading to those who can achieve well-informed judgment, explain their arguments, and deal with unexpected problems. It is concluded that critical thinking has been regarded as one of the main skills a university graduate must attain and most universities clarify this skill as a desirable attribute of the graduates. Thomas's research (2011) also mentions ideas of the students' skills to build up and how to integrate the students' perception of those skills with their learning and through the first-year assignments and activities. It would be emphasized that the process of academic development in the long run later would be based on these skills to bring up majors who can draw great decisions, address problems, and evaluate solutions effectively. 
According to Bassham et al. (2014), two kinds of inconsistency, logical and practical inconsistency could help to realize whether someone is consistent or not. Thus, when learners are guided to apply critical thinking skills through a list of steps, they may turn into creative thinkers (Facione \& Gittens, 2015).

\subsection{Writing skill}

Writing is one of the most challenging skills in learning and practising a language; indeed, this productive skill requires a wide range of competencies such as linguistic competence (grammar, structure and vocabulary), sociolinguistic competence and discourse knowledge. Therefore, language learners in general, English language learners in particular, might be challenged with a host of blocks in the writing process, and the leaners might also encounter the most frequent essay writing obstacles.

Several researchers have focused on writing skills, along with the other skill of language.

"Writing is both a physical and mental act. At the most basic level, writing is the physical act of committing words or ideas to some medium. On the other hand, writing is the mental work of inventing ideas, thinking about how to express them, and organizing them into statements and paragraphs that will be clear to a reader." (Nunan, 2003)

According to Richards (2008), sharpening steps in writing in either first or second language is one of the most difficult tasks students encounter. Kroll (2003) concludes that writing is a complicated process consisting of the mastery of numerous skills attributed to addressing the overall difficulty of writing for any language learner. Hyland (2003) concludes that composing is required in writing, which means the ability either to state pieces of information in the form of stories, or transform information into new compositions, as in argumentative essays. Therefore, it is viewed as a set of tasks that range from the more mechanical or formal aspects of writing to the more complex act of composing.

Moreover, Harmer (2007) states the writing skill is a long journey that should be carried out through different phases, namely drafting, editing, planning and final draft. In other words, the writing skill is believed to consist of planning, reflection and the organization of ideas. Scholars regard writing skill as a cognitive skill that writers must not only focus on sentence structure, lexical choices, spelling and punctuation but also master linguistic knowledge and integrate ideas coherently and cohesively in written discourse.

\subsection{Writing and critical thinking}

With the non-stop development of media in the modern era, there is no point in applying the traditional teaching methods where teachers can perform a pivotal role in sharing their knowledge with their students. In fact, students have more chance to become more autonomous learners. According to Tilfarlioglu and Ciftci (2011), these independent learners can figure out new topics and think distinctively by enhancing their ability and willingness to learn actively. Critical thinking has become included in the new teaching approaches. In fact, Patel (2013) refers to critical thinking as an ability that knowledgeable instructors should be trained or taught, where different techniques are applied to encourage students to practice critical thinking, especially in English language classes, because language is the key tool for accessing different fields.

It is studied that writing, one of the productive skills, helps improve learning in different ways by demonstrating that learning is on. Students have to be simultaneously exposed to four basic skills like listening, speaking, reading, and writing skills in English for specific purpose programs. As to thinking, writing is recognized as a medium of shadowing someone' own understanding (Alidmat \& Ayassrah, 2017). The productive feature of writing skill can be challenging if the tasks are not well-defined, because writing means detecting how to find the most influential aspect for transferring information. With discussion from Tran (1997), it can be seen that brainstorming in the target language will be struck by the English as a second language (ESL) learners when they disregard writing skill. These days, ESL instructors are required to prepare students to become future critical thinkers in a classroom environment that is changing and demanding and to ensure that these thinkers are competent and knowledgeable. That critical thinking should be evolved is important since possessing this ability can determine if ESL teachers will correctly determine what to do in the complex situations of ESL field.

Furthermore, when writing essays are discussed, Rafi (n.d.) highlights the role of critical thinking skills in boosting the numerous abilities and skills of ESL students. He also indicates the importance of those skills in writing ability and discovers that learners might become more competent in using a language if they are motivated and equipped with ways of incorporating critical thinking in their foreign language usage. He shows that students' performance shows their ideas are reflected more completely and their details are expressed logically if this occurs. The most obvious connection of critical thinking with writing is shown in the use of writing to illustrate the thinking process. Apparently, some students can better convey their thought than others because, for instance, they own a better ability of writing. Critical thinking has a particular association with the capacity to write clearly and precisely. This association is in providing the sequence and structure of the evidence and the broader conclusion of 
the topic. Critical thinking and writing are linked even further than writing down the information of the critical mind onto paper. In fact, a chance for review is widen as thoughts or ideas are produced in a written form. This is an opportunity to explore metacognition about someone's own critical thinking as determining whether the reading sources mention what needs to be said or not. Once writing represents thinking, ideas in mind can also be noticed by others, who are also likely to give comments and judge about it as in the process of peer review of student's academic papers or cooperative working in groups.

According to Vyncke (2012), critical thinking is claimed as one of the fundamental criteria and desired outputs in Western universities. Students are expected to adopt the built criteria in order to meet the requirements of successful writing at the university level. This means that they are required to express the ability of critical thinking in their academic essays in the form of an argument and by exhibiting related skills, be it evaluation and analysis. However, students are either unaware of the importance of judgments in writing or a lack of understanding of the concept of argument, evaluation and analysis. Nevertheless, it is not enough for students to define that critical thinking is a basic criterion of an effective essay. They should also recognize why and how critical thinking is beneficial to their development as a student. In this way, the students are consciously adopting the critical thinking skills they are aimed to obtain the most benefit from their studies.

In fact, activities to develop writing skills may concern the skills associated with critical thinking or vice versa. The tasks are relatively grouped according to settings in which they might be used in a university education curriculum. A complicated critical task with simple text might be of the same level of difficulty as a simple critical task with a text with complex issues. Moon (2008) gives suggestions on tasks that can be utilized in developing critical thinking in relation to writing skills. First, he offers five kinds of writing tasks that aim to develop the reflection and process of critical thinking in the early stages as followed:

1. Summarizing and the ability to write a conclusion;

2. Summarizing the evidence;

3. Taking different disciplinary perspectives;

4. Making a judgment;

5. Making a judgment, starting from another perspective.

To further the capacity in critical thinking, the following writing tasks are given:

1. The use of concept maps

2. A fictitious debate

3. Practice of peer review skills

4. Mark an essay in which critical thinking is represented

5. Recognition of the roles of referencing in the written form of critical thinking

6. Recognition and development of the 'playing with ideas' form of writing

Moreover, some more general writing exercises to support the written form of critical thinking are:

1. Short-answer tasks

2. A demonstration that people understand things differently

3. The identification of main points and important evidence

4. Looking critically at one's own work - drafting and redrafting

5. Practice in metacognition

6. 'Compare and contrast' tasks

7. Learners write a discussion between two theorists (could be fictitious or real) about a topic in their discipline

Finally, it is advisable to build up group-work activities in writing and critical thinking.

\section{Methodology}

The involved participants in this study were 120 English majors. The students were taking part in the Writing 2 course, which focuses on English short essay writing, after they finished the Writing 1 course that trains the students in sentence and paragraph writing skills. These objectives have to learn how to effectively acquire English academic essay writing as a compulsory subject of the English language curriculum and as an English competence requirement for their future jobs.

The Writing 2 course lasts for 60 in-class periods and 30 self-study periods, in which the students are required to write several types of short essays such as descriptive essays, narrative essays, opinion essays, comparison and contrast essays, and cause and effect essays. The main course book used is Effective Academic Writing 2 - the Short Essay, written by Savage A. and Mayer P. in 2005, Oxford Publisher. These consist of five parts in each unit, including stimulating ideas, brainstorming and outlining, developing your ideas, editing your writing, and putting it all together. 
The investigator collected data by means of questionnaires and classroom observations. First, the questionnaires were designed to ask students about their insights on the application and importance of critical thinking skills in their essay writing process. The questionnaire consists of 20 statements based on the suggested tasks by Moon (2008) to develop writing skills in relation to critical thinking skills. These statements also reflect the students' responses to the process of teaching the Writing course 2, in which writing activities employed critical thinking are involved intentionally. Second, six sections of students' in-class writing activities were observed to identify both benefits and challenges of applying critical thinking skills to students' essay writing process.

\section{Results and Discussion}

The presented table illustrates the findings on students' responses about critical thinking ability after in-class activities that are intended to develop their essay writing skills. Overall, most of the students agree with the given statements, while a relatively small number of students either do not favour these ideas or have no idea.

From the figures in the table, it can be said that teaching writing essays with critical thinking activities is welcomed by most of the students. The respondents show a positive trend towards the benefits that critical thinking brings to their learning. First, regarding the organization of essay writing (statements \#1, \#2, \#3 and \#4), more than three-quarters of the students admit that thanks to critical thinking activities such as organization determination, or peer correction activities, they can develop an essay better with organization. Meanwhile, although there is a lower degree of agreement in \#2 and \#4 compared to \#1 and \#2, there exists a high level of agreement in general (just over 60\%). When asked about the effects of critical thinking on other the development in writing aspects like task response, coherence and cohesion, grammar or vocabulary, just over a third disagree or have no idea, while there are still a large number of students favour of motivating ideas in critical thinking activities.

\begin{tabular}{|c|c|c|c|c|c|c|}
\hline & Statements & $\begin{array}{c}\text { Strongly } \\
\text { disagree } \\
(\%)\end{array}$ & $\begin{array}{l}\text { Disagree } \\
\text { (\%) }\end{array}$ & $\begin{array}{c}\text { Agre } \\
\text { e } \\
(\%)\end{array}$ & $\begin{array}{c}\text { Strongl } \\
\mathrm{y} \text { agree } \\
(\%)\end{array}$ & $\begin{array}{l}\text { No } \\
\text { idea } \\
(\%)\end{array}$ \\
\hline 1 & $\begin{array}{l}\text { I can understand clearly the organization of an essay thanks } \\
\text { to the peer correction activities. }\end{array}$ & 2.5 & 3.3 & 70.8 & 15.0 & 8.3 \\
\hline 2 & I can develop an essay better with the organization. & 3.3 & 3.3 & 79.2 & 8.3 & 5.8 \\
\hline 3 & I can develop an essay structurally. & 14.2 & 12.5 & 45.8 & 19.2 & 8.3 \\
\hline 4 & $\begin{array}{l}\text { I can express the ideas with different ways to give opinions } \\
\text { on the content of the essays. }\end{array}$ & 8.3 & 19.2 & 42.5 & 17.5 & 12.5 \\
\hline 5 & $\begin{array}{l}\text { I can develop ideas of an essay more coherently and logically } \\
\text { to convince readers. }\end{array}$ & 2.5 & 13.3 & 50.8 & 16.7 & 16.7 \\
\hline 6 & I can use ideas much related to the given topic. & 1.7 & 4.2 & 50.0 & 31.7 & 12.5 \\
\hline 7 & I can give evidence concisely and chiefly to persuade readers. & 3.3 & 5.8 & 46.7 & 36.7 & 7.5 \\
\hline 8 & I can differentiate between facts and opinions. & 0.8 & 5.8 & 48.3 & 35.8 & 9.2 \\
\hline 9 & I can distinguish main points from supporting points. & 5.0 & 9.2 & 60.0 & 18.3 & 7.5 \\
\hline 10 & I consider whether an idea is logical or not. & 4.2 & 10.8 & 45.0 & 27.5 & 12.5 \\
\hline 11 & $\begin{array}{l}\text { I check the evidence of an argument to decide if it is strong } \\
\text { enough. }\end{array}$ & 9.2 & 17.5 & 53.3 & 10.0 & 10.0 \\
\hline 12 & $\begin{array}{l}\text { In general, critical thinking skills help me improve my } \\
\text { academic essay writing skills. }\end{array}$ & 1.7 & 12.5 & 46.7 & 26.7 & 12.5 \\
\hline 13 & I can respond better to the assigned topic. & 2.5 & 14.2 & 57.5 & 17.5 & 8.3 \\
\hline 14 & $\begin{array}{l}\text { I search for information from other sources to expand my } \\
\text { knowledge about a topic. }\end{array}$ & 2.5 & 6.7 & 64.2 & 18.3 & 8.3 \\
\hline 15 & $\begin{array}{l}\text { I can question to understand more about a topic or if the } \\
\text { information is not provided enough. }\end{array}$ & 3.3 & 10.8 & 49.2 & 30.0 & 6.7 \\
\hline 16 & $\begin{array}{l}\text { I can break down the information to see how the idea is } \\
\text { organized and developed. }\end{array}$ & 5.0 & 9.2 & 39.2 & 37.5 & 9.2 \\
\hline 17 & $\begin{array}{l}\text { I consider new information to come up with a new } \\
\text { conclusion about a previous problem. }\end{array}$ & 4.2 & 11.7 & 48.3 & 28.3 & 7.5 \\
\hline 18 & $\begin{array}{l}\text { I can look critically at my friends' drafting and redrafting to } \\
\text { check grammar. }\end{array}$ & 9.2 & 13.3 & 47.5 & 23.3 & 6.7 \\
\hline 19 & I can improve a range of vocabulary significantly. & 13.3 & 14.2 & 41.7 & 25.0 & 5.8 \\
\hline 20 & $\begin{array}{l}\text { I gain many useful vocabularies to develop writing essays } \\
\text { academically. }\end{array}$ & 12.5 & 11.7 & 31.7 & 39.2 & 5.0 \\
\hline
\end{tabular}


The present survey could assume that activities in classes may enhance students' capacity for critical thinking. Students were required to be involved in several activities such as brainstorming, mapping, discussing, finding main ideas, searching information to support the ideas, and interpreting the evidence, expressing their thoughts, checking errors, correcting them, and whatever. Besides those, students had to analyze and evaluate the assigned topic before reaching suitable decisions to fulfill their requirements when working on tasks, projects or presentations. Such activities were firmly related to components of critical thinking such as analysis, evaluation, interpretation, inference, explanation, and self-regulation. That could explain why most English majors who had more experience in learning critical thinking skills responded positively to the questionnaire.

The above findings may be subjective as some students could wrongly respond to the questionnaires, so the researcher, as the direct instructor, needs more evidence to convince the audience by carrying out in-class observations while teaching Writing course 2. The results from direct observations of the teaching and learning process present both positive and negative effects of the teaching method with critical thinking activities. Students were faced with some difficulties at the first lessons because of their habit of writing without critical thinking. However, this case changed after finishing the first unit of the course; for example, they were ready and eager to be involved in the assigned tasks, both individually and in groups, employing critical thinking to help solve the problems. They had a better understanding of the process of writing essays effectively. In fact, the critical thinking activities were diversified and improved to assist students in gradually changing writing habits to write good academic essays.

For the teacher, applying critical thinking skills into writing classes generated underlying motivation for English majors. Particularly, the teacher could recognize the students' progress and achievements during 6 observed meetings among 15. Students' performance had been increasingly better day by day and the students' attitude towards writing tasks has changed. The majors felt more self-confident and more motivated to become good thinkers and deciders, which encourages them to write essays actively and effectively.

\section{Conclusion}

The present study aimed to investigate the students' perception of improving their essay writing skill through assigned critical thinking activities. To conclude, writing instructors should bear in mind that writing academic essays in English is not a plain task but a time-and-effort consuming thing for students to do. Also, at first glance, teaching essay writing skills may be easy thanks to the diversity of information sources which help students to get ideas, make decisions and produce effective essays without any obstacles. However, this teaching method might be faced with challenges if there is a lack of teaching frequently critical thinking, which encourages students to be much more confident and self-esteem in their writing learning process. Hence, the present study is an attempt to investigate understanding on applying this method into teaching writing essays for English majors at HUFI. Being familiar with the insights that HUFI English majors gain would help instructors better understand their own teaching procedures and find useful ways to create well-rounded essay composing learners. English learners are subject to meet different difficulties that prevent them from writing effective essays, but this can be addressed by connecting teaching writing skills and critical thinking skills. In addition, it has been found that less attention has been paid to critical thinking, leading to the lack of motivation to develop good essays. To remove this obstruction, it was recommended for both students and teachers to closely look at critical thinking application.

Funding: This research received no external funding.

Acknowledgements: My completion of this research paper could not have been accomplished without the support of the board of management in HUFI Faculty of Foreign Languages and my students' participation. Their contributions are sincerely appreciated and gratefully acknowledged.

Conflicts of Interest: The authors declare no conflict of interest.

\section{References}

[1] Alidmat, A. O. H., \& Ayassrah, M. A. (2017). Development of critical thinking skills through writing tasks: challenges facing Maritime English students at Aqaba College. International Journal of Higher Education, 6(3), 82-90. doi: 10.5430/ijhe.v6n3p82.

[2] Bacha, N. N. (2010). Teaching the academic argument in a university EFL environment. Journal of English for Academic Purposes, 9(3), 229241

[3] Bassham, G., Irwin, W., Nardone, H., \& Wallace, Ja. M. (2014). Critical thinking: A student's introduction (4th ed.) The McGraw Hill.

[4] Cottrell S. (2005). Critical Thinking Skills Developing Effective Analysis and Argument. Palcrave Macmillan Itd.

[5] Doyle, 2020 https://www.thoughtco.com/critical-thinking-definition-with-examples-2063745

[6] Daniel, M., \& Auriac, E. (2011). Philosophy, critical thinking and philosophy for children. Educational Philosophy and Theory, 43(5), 415-435. https://doi.org/10.1111/j.1469- 5812.2008.00483.x

[7] Facione, P. A. (2009). Critical thinking. The California Academic Press.

[8] Facione, P., \& Gittens, C. A. (2015). Think critically. New York, NY: Pearson Education

[9] Fisher A. (2011). Critical Thinking - An Introduction (Second edition). Cambridge University Press.

[10] Harmer, J. (Ed.). (2007). How to Teach Writing (5 $5^{\text {th }}$ edition). Person Education Limited. 
[11] Hyland, K. (2003). Second Language Writing. Cambridge: Cambridge University Press.

[12] Kroll, B. (2003). Exploring the Dynamic of second Language Writing. New York: CUP.

[13] McMillan, J. H. (1987). Enhancing college students' critical thinking: A review of studies. Research in Higher Education, 26(1), 3-29. https://doi.org/10.1007/bf00991931

[14] McCutcheon, L.E., \& Apperson, J.M. (1992). Relationships among critical thinking, academic achievement, and misconceptions about psychology. Psychological Reports, 71(2), 635-639.

[15] Moon, J. (2008). Critical Thinking - An exploration of theory and practice. Routledge - Taylor \& Francis Group.

[16] Nugent, P. M., \& Vitale, B. R. (2008). Fundamentals success: A course review applying critical thinking to test taking (2 nd ed.). Philadelphia, PA: F. A. Davis Company.

[17] Nunan, D. (2003). Practical English Language Teaching. International Edition, McGraw-Hill, Singapore, 88.

[18] Patel, D.M. (2013). Effectiveness of critical thinking program on students of class IX in relation to gender. International Journal for Research in Education, 2(7), 16-19.

[19] Rafi, M. S. (n.d.). Promoting Critical Pedagogy in Language Education. International Research Journal of Arts \& Humanities (IRJAH), 37, 6373.

[20] Richards, J. C. (2008). Second Language Teacher Education Today. RELC Journal, 39, 158-177.

[21] Richards, J. C. \& Schmidt, R. (2002). Longman dictionary of language teaching \& applied linguistics (3rd Ed.). Malaysia: Pearson Education Book.

[22] Thomas, T. A. (2011). Developing First Year Students' Critical Thinking Skills. Asian Social Science, 7(4). doi:10.5539/ass.v7n4p26

[23] Tilfarlioglu, F. Y., \& Ciftci, F. S. (2011). Supporting self-efficacy and learner autonomy in relation to academic success in EFL classrooms. Theory and Practice in Language Studies, 1(10), 1284-1294. doi:10.4304/tpls.1.10.1284-1294.

[24] Tran, H. (1997). How to become a writer? Orlando: Teachers of English to Speakers of other Languages Convention.

[25] Vyncke, M. (2012). The concept and practice of critical thinking in academic writing: an investigation of international students' persceptions and writing experience.

[26] Wang, Y. H. (2009). Incorporating critical thinking skills into an English conversation program. European Journal of Social Sciences, 11(1), 5160. 